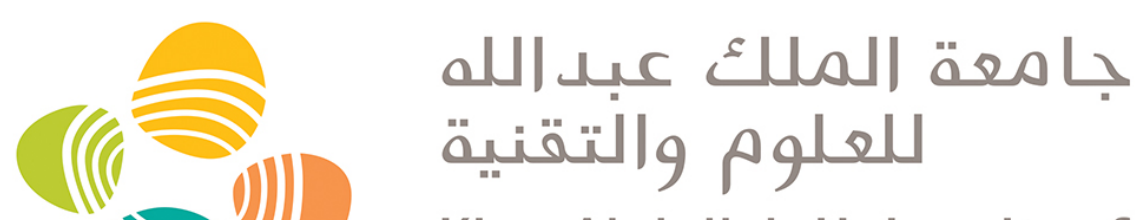 \\ King Abdullah University of \\ Science and Technology
}

\section{Ecohydrographic control on the community structure and vertical distribution of pelagic Chaetognatha in the Red Sea}

\begin{tabular}{|c|c|}
\hline Item Type & Article \\
\hline Authors & $\begin{array}{l}\text { Karati, Kusum Komal; Al-Aidaroos, Ali M.; Devassy, Reny P.; El- } \\
\text { sherbiny, Mohsen M.; Jones, Burton; Sommer, Ulrich; Kürten, } \\
\text { Benjamin }\end{array}$ \\
\hline Citation & $\begin{array}{l}\text { Karati KK, Al-Aidaroos AM, Devassy RP, El-Sherbiny MM, Jones } \\
\mathrm{BH} \text {, et al. (2019) Ecohydrographic control on the community } \\
\text { structure and vertical distribution of pelagic Chaetognatha in the } \\
\text { Red Sea. Marine Biology 166. Available: http://dx.doi.org/10.1007/ } \\
\text { s00227-019-3472-x. }\end{array}$ \\
\hline Eprint version & Post-print \\
\hline DOI & $10.1007 / \mathrm{s} 00227-019-3472-x$ \\
\hline Publisher & Springer Nature \\
\hline Journal & Marine Biology \\
\hline Rights & $\begin{array}{l}\text { The final publication is available at Springer via http:// } \\
\text { dx.doi.org/10.1007/s00227-019-3472-x }\end{array}$ \\
\hline Download date & 07/05/2021 12:38:25 \\
\hline Link to Item & http://hdl.handle.net/10754/630971 \\
\hline
\end{tabular}




\section{Ecohydrographic control on the community structure and vertical distribution of pelagic \\ 2 Chaetognatha in the Red Sea}

3

4 Kusum Komal Karati ${ }^{1,2 * \#}$, Ali M. Al-Aidaroos ${ }^{3}$, Reny P Devassy ${ }^{3}$, Mohsen M. El-Sherbiny ${ }^{3,4}$,

5 Burton H. Jones ${ }^{5}$, Ulrich Sommer ${ }^{6}$, Benjamin Kürten ${ }^{5 *}, 6$

6 Affiliations

$7 \quad{ }^{1}$ CSIR - National Institute of Oceanography, Regional Centre Kochi, Kochi 682018, India

$8 \quad{ }^{2}$ Centre for Marine Living Resources and Ecology, Kochi, 682037, India, * present address

$9{ }^{3}$ King Abdulaziz University, Department of Marine Biology, Faculty of Marine Sciences, P.O.

10 Box 80207, Jeddah 21589, Kingdom of Saudi Arabia

$11{ }^{4}$ Suez Canal University, Department of Marine Science, Faculty of Science, Ismailia 41522,

12 Egypt

$13{ }^{5}$ King Abdullah University of Science and Technology (KAUST), Red Sea Research Center

14 (RSRC), Biological and Environmental Sciences \& Engineering Division (BESE), Thuwal,

15 23955-6900, Saudi Arabia, * present address

$16{ }^{6}$ GEOMAR Helmholtz Centre for Ocean Research Kiel, Marine Ecology, Düsternbrooker Weg

1720,24105 Kiel, Germany

\#Correspondence to: Kusum Komal Karati

20 Email: kusum.kk1@gmail.com

21 Phone: +919895305666

22 ORCID IDs

23 KK orcid.org/0000-0001-9627-7466

24 BK orcid.org/0000-0003-0328-7847

25 BHJ orcid.org/0000-0002-9599-15

26 Disclosure statement

27 BK and AA conceived the study. BK, ME, RD and AA carried out fieldwork, analyzed the

28 zooplankton samples, and processed the data. KK provided taxonomic identifications of

29 Chaetognatha, interpreted the data, and drafted the manuscript. BK, US, and BJ provided 30 editorial advice. 


\section{Abstract}

32 The present study details the effects of basin-scale hydrographic characteristics of the Red Sea

33 on the macroecology of Chaetognatha, a major plankton component in the pelagic realm. The

34 hydrographic attributes and circulation of the Red Sea as a result of its limited connection with

35 the northern Indian Ocean make it a unique ecohydrographic region in the world ocean. Here, we

36 aimed to identify the prime determinants governing the community structure and vertical

37 distribution of the Cheatognatha in this ecologically significant world ocean basin. The intrusion

38 of Gulf of Aden Water influenced the Chaetognatha community composition in the south,

39 whereas the overturning circulation altered their vertical distribution in the north. The existence

40 of hypoxic waters $\left(<100 \mu \mathrm{mol} \mathrm{kg}^{-1}\right)$ at mid-depth also influenced their vertical distribution. The

41 detailed evaluation of the responses of the different life stages of Chaetognatha revealed an

42 increased susceptibility of adult individuals to hypoxic waters compared to immature stages.

43 Higher oxygen demands of the adults for the egg and sperm production might have prevented

44 them from inhabiting the oxygen deficient mid-depth zones. The carbon and nitrogen content of

45 the Copepoda and Chaetognatha communities and the quantification of the predation impact of

46 Chaetognatha on Copepoda based on the feeding rate helped in corroborating the significant

47 trophic link between these two prey-predator taxa. The observed influences of physical and

48 chemical attributes on the distribution of Chaetognatha can be used as a model example for the

49 role of the hydrography on the zooplankton community of the Red Sea.

50 Keywords: Biogeography; Chaetognatha; Ecohydrography; Macroecology; Red Sea;

\section{Zooplankton}




\section{Introduction}

55 The phylum Chaetognatha embraces a major component of pelagic plankton in the global oceans

56 and their marginal seas (Nair 1978; Bohata and Koppelmann, 2013; Terazaki 2013; Kürten et al.

57 2014). As carnivores, chaetognaths are known to consume $\sim 1$ to 12 prey day $^{-1}$ ranging from

58 oligotrophic to productive environments (Kimmerer 1984; Kehayias 2003) and therefore play a

59 pivotal role in the trophodynamics of marine ecosystems. Their sensitivity to the physical and

60 chemical environment leading to their association with specific water masses makes them

61 suitable bioindicators of ecohydrographic provinces (Nagai et al. 2006; Buchanan and Beckley

62 2016) and for regions with increased primary productivity and the underlying physical processes

63 (e.g. eddies, fronts, and upwelling) (Kusum et al. 2014; Lima 2014; Nair et al. 2015).

64 The Red Sea, geographically positioned between the Asian and African continents and

65 characterized by an area of $4.51 \times 10^{5} \mathrm{~km}^{2}$ and a length of $\sim 2000 \mathrm{~km}$ is a semi-enclosed inlet of

66 the Indian Ocean (Sofianos and Johns 2002). The high evaporation rates ( $\left.>2 \mathrm{~m} \mathrm{yr}^{-1}\right)$, low

67 precipitation $\left(0.05-0.15 \mathrm{~m} \mathrm{yr}^{-1}\right)$ and negligible river discharges makes the Red Sea one of the

68 saltiest ocean basins with a salinity range of 36 to 41 (Miller 1964; Grasshoff 1969; Maillard and

69 Soliman 1986). Moreover, an exchange-flow between the Red Sea and the Indian Ocean in the

70 south and the overturning circulation in the north influence the salinity, sea surface temperature,

71 and nutrient availability of the Red Sea (Sofianos and Johns 2002, 2003). Thus, a detailed

72 understanding about the influence of its ocean dynamics on the biotic community is utmost

73 important to delineate the ecosystem status, health, and trophic dynamics of this unique ocean

74 basin.

75 The goal of the present study was to understand the integrated effects of both abiotic

76 (hydrographic regime) and biotic components structuring Chaetognatha community in the Red 
77 Sea. The study is sequel to latitudinal assessments of phytoplankton and zooplankton

78 biodiversity and trophic dynamics in nearshore coral reefs (Kürten et al. 2015; Al-Aidaroos et al.

79 2017; Devassy et al. 2017). Most other recent studies focused on the detailed taxonomic and

80 biogeographic descriptions of the dominant zooplankton taxon Copepoda (e.g. Al-Aidaroos et al.

81 2016; El-Sherbiny et al. 2007, 2017). However, comprehensive studies pertaining to the

82 macroecology of Chaetognatha with 19 species from this region are scarce and limited to their

83 distribution in the upper water column in coral reefs (Ducret 1973; Halim 1984; Casanova 1985,

84 1986; Al-Aidaroos et al. 2017).

85 We hypothesized that the oceanographic features i.e. the northward intrusion of Gulf of Aden

86 Water (GAW), the anti-estuarine overturning circulation, and vertical gradients in physical and

87 chemical variables play a crucial role in the macroecology of Chaetognatha in the Red Sea. To

88 address our goals, the latitudinal and vertical distribution of the Chaetognatha community and

89 their life stages were related to abiotic variables (temperature, salinity, dissolved oxygen and

90 depth) to identify the influence of the hydrography on their distribution. Following the $\beta$ -

91 diversity approach, we aimed to identify biotic dissimilarities generated by the variability in the

92 physical and chemical attributes of the basin.

$94 \quad$ Materials and Methods

95 Study area and sampling

96 Sampling was carried out from $8^{\text {th }}$ to $20^{\text {th }}$ April, 2012 onboard RV Pelagia (cruise 64PE351)

97 (Fig. 1). Considering the geographical position of the basin, the sampling sites were selected to

98 cover the ecohydrographic gradients of the Red Sea over a distance of $\sim 1300 \mathrm{~km}$.

99 Physical and chemical variables 
At all stations, a SBE 911 CTD (Sea-Bird Electronics, USA) was deployed to obtain vertical profiles of temperature and salinity. The CTD was equipped with a SBE 43 dissolved oxygen (DO) sensor to obtain DO profiles of the water column. A detailed description of water mass characteristics (excluding DO) has been presented by Kürten et al. (2016).

\section{Biological variables}

A multiple opening-closing net (type Midi; Hydro-Bios, FRG) with mesh size of $330 \mu \mathrm{m}$ and mouth area of $1 \mathrm{~m}^{2}$ was used for meso- and macrozooplankton sampling. The net was hauled in stratified oblique mode (sensu Wiebe et al., 2014) to obtain samples from five depths strata i.e., 0 $-100 \mathrm{~m}, 100-200 \mathrm{~m}, 200-300 \mathrm{~m}, 300-500 \mathrm{~m}$, and $500-1000 \mathrm{~m}$ at a tow speed of $1 \mathrm{knot}$. At sampling locations with depth less than $1000 \mathrm{~m}$, the deeper waters were sampled from near bottom to $500 \mathrm{~m}$ (Supplementary Table 1). On deck, zooplankton samples were immediately preserved in $4 \%$ buffered formalin for detailed taxonomic evaluation. Copepoda and Chaetognatha were sorted and enumerated under a stereomicroscope (SMZ168, Motic, FRG) and abundances were calculated based on the volume of water filtered and expressed as $\mathrm{Ind}^{-3}$ (Harris et al., 2000). The identification of the Chaetognatha community at the species level was carried out following standard identification protocols (Nair 2003) and available literature for the Red Sea (Casanova 1986; Echelman and Fishelson 1990).

To have a better understanding of their vertical distribution, the weighted mean depth of the Chaetognatha species was calculated following Dupont and Aksnes (2012) as:

$$
\begin{gathered}
Z_{m}=\sum_{i=1}^{n} a_{i} d_{i} z_{i} / \sum_{i=1}^{n} a_{i} d_{i} \\
Z_{s}=\sqrt{\left(\sum_{i=1}^{n} a_{i} d_{i} z_{i}^{2} / \sum_{i=1}^{n} a_{i} d_{i}\right)-Z_{m}^{2}}
\end{gathered}
$$


121 Where, $Z_{m}$ is the weighted mean depth (m) of each species, $Z_{s}$ is the corresponding standard

122 deviation ( $\pm 1 \mathrm{SD}), a_{i}$ is the abundance (ind $\mathrm{m}^{-3}$ ) of each species along stratum $i, d_{i}$ is the

123 thickness (m) of the stratum $i, z_{i}$ is the corresponding mid-depth (m) of stratum $i, n$ is the total

124 number of sampled strata.

125 Although the maturity period in Chaetognatha varies among species, which can be assessed based

126 on their ovarian development, all Chaetognatha specimens were assigned to one of three maturity

127 stages (McLaren 1969; Zo 1973) to understand the varied responses of the growth stages to

128 hydrographic attributes. In brief, Stage I (immature individuals) lack visible ovaries, in Stage II

129 (maturing) developing ova are present, whereas Stage III (matured) have one or more mature ova.

130 The spent individuals were also included under the stage III category (Kusum et al. 2011).

131 Carbon and nitrogen (hereafter $\mathrm{C}$ and $\mathrm{N}$ ) content of Chaetognatha and Copepoda was determined

132 using elemental analysis as detailed in Kürten et al. (2016). C and N data were available for

133 dominant Copepoda genera only. In case of Chaetognatha, the total community was considered.

134 The information on the relative trophic position of the Chaetognatha was used from Kürten et al.

135 (2016).

136 Statistical analyses

137 Abundances of both Copepoda and Chaetognatha in different depth strata were compared using

138 one-way ANOVAs, with two-tailed P-values and 95\% confidence intervals (Graphpad prism

139 version 5.01). Prior to the analysis, the Kolmogorov-Smirnov normality test was performed to

140 determine whether parametric or non-parametric ANOVA was applicable. Relationships between

141 the abundance of Copepoda and Chaetognatha were identified using Pearson correlation with

142 two-tailed P-values and 95\% confidence intervals (Graphpad prism). 
143 Unconstrained non-metric multidimensional scaling (NMDS) is often significant in the

144 ordination of biological variables. To explain the similarities in the composition of the

145 Chaetognatha community along different depth strata, we used NMDS analysis using PRIMER 6

146 (Clarke and Gorley 2006) based on the Bray-Curtis similarity matrix of the fourth-root

147 transformed species-wise abundance of each depth zones. Clusters based on $75 \%$ similarity were

148 overlaid on the NMDS plot to describe relationships of the Chaetognatha distribution among the

149 sampling depths. In addition, a second NMDS plot was used to identify the similarity in the

150 distribution of the Chaetognatha species based on their abundance along the horizontal and

151 vertical scale.

152 The $\alpha$ - and $\beta$-diversities of the Chaetognatha community were used to assess the biodiversity and

153 the variation in species identity among the sampling locations (Anderson et al. 2011). First, the

154 Shannon-Wiener species diversity index $\left(H^{\prime}\right)$ was estimated using PRIMER 6. Inter-site

155 variability was assessed using the index of multivariate dispersion (MVDISP, Warwick and

156 Clarke 1993).

157 The constrained Redundancy analysis (RDA) was used as in multivariate space it best explains

158 the linear relationships between response and explanatory variables (Van den Wollenberg 1977).

159 The advantage of RDA is that it displays a simultaneous representation of the observations of the

160 response variables (Chaetognatha) and explanatory variables (physical and chemical variables

161 and Copepoda), and the position of the variables in the tri-plot helps visualizing their

162 relationships.

163

164 Results

165 Physical and chemical environment 
Sea surface temperatures (at $3 \mathrm{~m}$ depth) varied between 23.1 and $28.5^{\circ} \mathrm{C}$ (average $\pm \mathrm{SD}, 26 \pm 1.8$ ${ }^{\circ} \mathrm{C}$ ) and decreased towards the north (Fig. 2a). In the vertical temperature profile, a strong gradient was observed in the upper $200 \mathrm{~m}$ of the water column and more pronounced in the south (Fig. 2a). Sea surface salinity also showed a latitudinal gradient with a marked increase towards the north (range $37.3-40.4$; average $39 \pm 1.1$ ) (Fig. 2b). The stratification in the vertical salinity profile was evident in the upper $200 \mathrm{~m}$ with stronger gradient towards the south (Fig. 2b). Spatial variation in the surface DO was marginal (average $253.9 \pm 19.2 \mu \mathrm{mol} \mathrm{kg}^{-1}$ ), with a sharp gradient in the vertical profile below $50 \mathrm{~m}$ (Fig. 2c). Low DO $\left(<100 \mu \mathrm{mol} \mathrm{kg}^{-1}\right)$ at depths were evident throughout the study region. In the south, the oxygen minimum layer was observed between $150-800 \mathrm{~m}$ whereas in the north it was between $400-650 \mathrm{~m}$ (Fig. 2c).

\section{Copepoda abundance}

The upper $100 \mathrm{~m}$ contributed $79.3 \%$ to the total copepod abundance over the entire $1000 \mathrm{~m}$ water column. Copepoda abundances in this layer varied between 37.9 and 74.9 ind $\mathrm{m}^{-3}$ with an average abundance of $53.4 \pm 14.3$ ind $\mathrm{m}^{-3}$ (Supplementary Fig. 1). The variation in the abundance along different depth zones was significantly different (one-way ANOVA, $F_{4,25}=$ $67.63, P<0.001)$. While there was a pronounced decrease from the $0-100 \mathrm{~m}$ stratum to the 100 $-200 \mathrm{~m}$ stratum, the further decrease in abundance was not consistent with increasing depth (Supplementary Fig. 1a). The abundance was observed to be lowest at the $200-300 \mathrm{~m}$ depth at all sampling sites except off Farasan where it was lowest at 300-500 m (Supplementary Fig. 1).

\section{Chaetognath abundance, community structure and vertical distribution}

Similar to the copepod community, Chaetognatha were most numerous in the upper $100 \mathrm{~m}$ contributing to $74.2 \%$ to their total population over the entire sampling depths (Supplementary Fig. 1). The variation in the Chaetognatha abundance over depths were statistically significant 
189 (one-way ANOVA, $F_{4,25}=10.84, P<0.001$ ). The Chaetognatha abundances sharply decreased 190 below $100 \mathrm{~m}$ at most sites and abundances showed an intermediate low at $100-200 \mathrm{~m}$ depth 191 before reaching $500-1000$ m (Supplementary Fig. 1). A total of 17 species belonging to 11 192 genera were observed (Table 1). Although Chaetognatha abundance was higher in the upper 100 193 $194200 \mathrm{~m}$ and $500-1000 \mathrm{~m}$ (12 each, respectively). Flaccisagiita enflata was the dominant species 195 196 197 198 199 200 in the upper two depth strata, whereas Decipisagitta decipiens dominated depths below $500 \mathrm{~m}$ (Fig. 3). Nine species (Krohnitta pacifica, Krohnitta subtilis, Aidanosagitta regularis, Decipisagitta decipiens, Flaccisagitta enflata, Flaccisagitta hexaptera, Ferosagitta ferox, Sagitta bipunctata, and Zonosagitta pulchra) were observed at all stations in one or more depth strata despite different abundances. Among the epipelagic Chaetognatha, nine species were observed in the entire $1000 \mathrm{~m}$, and five of them had $>75 \%$ of their abundance in the upper $100 \mathrm{~m}$ (Table 1 and Supplementary Fig. 2). The epipelagic Pterosagitta draco and Zonosagitta pulchra were observed in the upper $500 \mathrm{~m}$, and showed higher abundances in the upper $100 \mathrm{~m}(>75 \%)$, whereas the distribution of Zonosagitta bedoti was restricted to the upper $300 \mathrm{~m}$ (Table 1). Of the mesopelagic species, only Decipisagitta decipiens was present throughout the $1000 \mathrm{~m}$ and had higher abundances at 200 - 500 m. Eukrohnia fowleri and Pseudosagitta maxima were observed only below 200 m especially with high preferences for waters below $300 \mathrm{~m}$ (Table 1). Although the weighted mean depth $\left(Z_{m}\right)$ of the chaetognaths varied among species, it was less than $100 \mathrm{~m}$ depth for majority of the epipelagic species (Fig. 4). The $Z_{m}$ of the mesopelagic species ranged between 352 and $556 \mathrm{~m}$ (Fig. 4). Spatially, the occurence of the majority of the epipelagic species in the deeper layers was higher in Duba, the northernmost station

211 (Supplementary Table 2). Based on the maturity stages of the species of chaetognaths, the 
212 immature individuals dominated at most depths (Fig. 5). Both maturing and mature individuals

213 of the majority of the epipelagic species had a preference for surface waters $(0-100 \mathrm{~m})$ (Fig. 5)

214 Chaetognatha-Copepoda interrelationship

215 A positive relation was observed between the abundances of Copepoda and Chaetognatha

216 (Pearson correlation; $R=0.761, P<0.01$ ). The ratio of the abundance of the Copepoda and

217 Chaetognatha varied among the depth layers (Fig. 6). It was relatively higher in the upper two

218 layers and in the deeper $500-1000 \mathrm{~m}$ depth, but lower in the mid-depth waters (median 7.8,

$21913.9,1.7,8$, and 14.3, in $0-100 \mathrm{~m}, 100-200 \mathrm{~m}, 200-300 \mathrm{~m}, 300-500 \mathrm{~m}$ and $500-1000 \mathrm{~m}$

220 depth, respectively).

221 Table 2 displays the $\mathrm{C}$ and $\mathrm{N}$ content of Chaetognatha and of the dominant genus of the

222 Copepoda. The $\mathrm{C}$ and $\mathrm{N}$ of Chaetognatha was 34.12 and $9.09 \%$ of their dry weight, respectively.

223 In Copepoda, the percentage of $\mathrm{C}$ varied between $18.07 \%$ to $51.65 \%$ of their dry weight, and in

224 case of $\mathrm{N}$ it ranged between $4.23 \%$ and $12.58 \%$ among the different genera. To approximate the

$225 \mathrm{C}$ and $\mathrm{N}$ content of the total Copepoda community, an average $\mathrm{C}$ and $\mathrm{N}$ content of the dominant

226 Copepoda genera were used for the remaining Copepoda community. Considering the total

227 volume of the upper $100 \mathrm{~m}$ of the Red Sea as $3.433 \times 10^{13} \mathrm{~m}^{-3}$, Chaetognatha contained $\sim 25,222 \mathrm{t}$

$228 \mathrm{C}$ and 3,719 $\mathrm{t} \mathrm{N}$, respectively. In case of Copepoda, the elemental content was $95451 \mathrm{t}$ and 21865

$229 \mathrm{t}$ for $\mathrm{C}$ and $\mathrm{N}$, respectively. The total amount of $\mathrm{C}$ in the Chaetognatha was $26.4 \%$ of the total C

230 content of Copepoda and in case of $\mathrm{N}$ content this value was 30.7\%. The relative trophic position

231 for the Chaetognatha community was $3.2 \pm 0.4(\min 2.7 \max 4.1 ; \mathrm{n}=31$ samples, a composite of

232514 specimens, Kürten et al. 2016).

233 The NMDS plot based on the abundance of Chaetognatha species along the depth layers,

234 exhibited a discrete ordination of the upper $0-100 \mathrm{~m}$ and deeper $500-1000 \mathrm{~m}$ from the other 
235 depth zones with a Kruskal stress value of 0 (Fig. 7a). The overlay cluster based on the $75 \%$

236 similarity level revealed a group of the mid-depth zones together $(100-200 \mathrm{~m}, 200-300 \mathrm{~m}$, and

$237300-500 \mathrm{~m})($ Fig. 7a). The NMDS plotted to evaluate the similarity in the distribution of the

238 Chaetognatha species revealed a large group with majority of the epipelagic species and another

239 group with two mesopelagic species based on the $40 \%$ similarity (Fig. $7 b$ ).

$240 \alpha$ and $\beta$-diversity

241 The species diversity $\left(H^{\prime}\right)$ varied both spatially and temporally and based on the depth-wise

242 average value it was maximum at $200-300 \mathrm{~m}$ (average $2.29 \pm 0.45,2.3 \pm 0.88,2.64 \pm 0.49$,

$2432.61 \pm 0.54$, and $2.22 \pm 0.6$, in $0-100 \mathrm{~m}, 100-200 \mathrm{~m}, 200-300 \mathrm{~m}, 300-500 \mathrm{~m}$, and $500-$

$2441000 \mathrm{~m}$, respectively). The relative variability of the Chaetognatha assemblages within each

245 stations (i.e. intragroup $\beta$-dissimilarity) exhibited the lowest value off Duba (Supplementary

246 Table 3, based on the MVDISP analysis). The pairwise inter-station $\beta$-dissimilarity based on the

247 index of multivariate dispersion (IMD) showed varying results among sites (Supplementary

248 Table 3). In general, the southernmost two stations had high IMD values with most of the other

249 sampling locations (Supplementary Table 3). The northernmost station had a high dissimilarity

250 with its nearby station Mabahiss (0.62).

251 Redundancy analysis (RDA)

252 The RDA triplots indicated the preferred environment of the Chaetognatha species. Most of the

253 epipelagic Chaetognatha were positively correlated with DO and the abundance of their

254 dominant prey Copepoda (Fig. 8a). The abundances of mesopelagic Eukrohnia fowleri and

255 Pseudosagitta maxima also exhibited a similar result having positive relation with the abundance

256 of Copepoda and DO (Fig. 8b).

257 


\section{Discussion}

259 The ecohydrographic framework of the Red Sea helped to understand the complexity in the

260 biotic-abiotic relationships of the Chaetognatha community. The lower salinity in the upper 100 $\mathrm{m}$, chiefly up to $19^{\circ} \mathrm{N}$, relates to the inflow of GAW into the Red Sea and corroborates earlier

262 observations and modeling studies (Stubbings 1939; Maillard and Soliman 1986; Sofianos and

263 Johns 2007). The overturning circulation in the northern Red Sea is another important factor that 264 governs the hydrography of this basin. The outcome of this overturning circulation is the sinking 265 of surface waters in the north which was clearly evident in the salinity structure around $27^{\circ} \mathrm{N}$ 266 (Fig. 2b). The winter surface cooling leads to deep convection in the northern Red Sea and 267 results in a near-homogeneous water up to subsurface layers (Kürten et al. 2016; Fig. 2).

268 However, the sinking of the isothermal lines at the northernmost location supports the salinity 269 based observation of the sinking of water to deeper layers.

270 The variability in the physical and chemical characteristics in the Red Sea influenced the 271 plankton distribution. In the upper $100 \mathrm{~m}$ water, the Chaetognatha abundance was high in 272 Atlantis II and off Duba. At the Atlantis II, upwelling of nutrient-rich water contributed to the 273 conspicuous preponderance of diatoms (Kürten et al. 2016). It is suggested that the higher 274 availability of diatoms supported increased abundances of Copepoda and in turn sustained higher 275 Chaetognatha abundance in this location. Similarly, the increased abundance of diatoms off 276 Duba also offered sufficient food for zooplankton as indicated by increased chlorophyll $a$ and 277 particulate organic nitrogen as proxies for phytoplankton biomass (Kürten et al. 2016).

278 The existence of hypoxic waters helps explaining the sudden drop in the Chaetognatha abundance 279 below $100 \mathrm{~m}$. Chaetognatha are sensitive to low DO, as was shown, for example, in the adjacent 280 Arabian Sea where Chaetognatha are scarce in oxygen deficient zones (Kusum et al. 2011). Hence, 
281 the sharp gradients in DO leading to hypoxia in the $100-200 \mathrm{~m}$ in the Red Sea are likely to lower 282 Chaetognatha abundances at this depth. The $Z_{m}$ of majority of the epipelagic species was less than $283100 \mathrm{~m}$ indicating their preference to the upper oxygenated water. The $Z_{s}$ varied among the species 284 and the relatively lower $Z_{s}$ in epipelagic species like Zonosagitta bedoti and Zonosagitta pulchra 285 points out their restricted vertical distribution (Fig. 4). The marked positive relation between the 286 abundance of most of the Chaetognatha species and DO corroborates the vital role of DO in 287 structuring the Chaetognatha population (Fig. 8), a relationship typical for plankton distribution in 288 289 $\mathrm{m}$ was reflected in the separation of this depth stratum from the aphotic zone (Fig. 7a). Among the 291 nine epipelagic Chaetognatha observed, five species had $>75 \%$ of their abundance in the upper $292100 \mathrm{~m}$, which points towards their preferences for relatively well-oxygenated surface waters. The 293 group of the majority of the epipelagic Chaetognatha species in the NMDS plot (Fig. 7b) 294 corroborated their preferences for the similar environments. The higher abundance of Copepoda, 295 their primary prey at this depth, might have also favored their higher sustenance and abundances. 296 Although gut content analysis of the Chaetognatha was not carried out in the present study, 297 Copepoda are typically the most preferred prey of Chaetognatha (Kehayias 2003; Giesecke and 298 González 2004; Terazaki 2004; Yoon et al. 2016). The marked positive correlation between prey 299 and predators confirms the important trophic link. In the RDA analysis, the observed positive 300 association of the majority of the epipelagic and mesopelagic species of Chaetognatha with the 301 abundance of Copepoda (Fig. 8) further validates their trophic relations. The relative trophic 302 position for the Chaetognatha community in this study was $3.2 \pm 0.4$ where producer species were 303 assigned to trophic level 1, and the consumer values range from 2 (primary consumers) to 5 or 
greater. This relative trophic position exhibits their importance as the secondary consumer in the

305 pelagic ecosystem. The feeding rate of the Chaetognatha has been found to vary among tropical, 306 temperate, and polar organisms (Oresland 2000; Giesecke and González 2012). Flaccisagitta 307 enflata, the dominant Chaetognatha in the upper $300 \mathrm{~m}$ is capable of consuming up to 10 - 12 prey 308 items day ${ }^{-1}$, whilst its feeding rate depends on prey availability (Reeve 1980; Kimmerer 1984). 309 The higher values of the ratio of the abundance of the Copepoda and Chaetognatha (median 7.8, 310 and 13.9 , in $0-100 \mathrm{~m}$, and $100-200 \mathrm{~m}$, respectively) indicates a favorable environment for the

311 Chaetognatha. The lower ratios in the mid-depth waters (median 1.7, and 8, in $200-300 \mathrm{~m}, 300$ 312 $-500 \mathrm{~m}$, respectively) indicates a food-limited environment for the Chaetognatha compared to the upper layers. This scenario differs from the northern Arabian Sea, where the prey - predator ratio 314 was higher in the acute oxygen depleted mid-depth waters than in surface waters (Kusum et al. 315 2011).

The abundance of both Copepoda and Chaetognatha in the upper $100 \mathrm{~m}$ was $>70 \%$ of 317 their total population in the entire $1000 \mathrm{~m}$ water column and hence based on the information in 318 the available literature we estimated the predation pressure of the Chaetognatha on the Copepoda 319 in this stratum. We considered the predation impact (the percentage of the copepod standing 320 stock consumed per day) of the dominant species $F$. enflata and also of the total Chaetognatha 321 community. To calculate the predation impact, the prey day ${ }^{-1}$ for each individual of 322 Chaetognatha was estimated based on the result observed in the upper $100 \mathrm{~m}$ by Kehiyas (2003, 323 Tables 4 and 5) in the Mediterranean Sea ( $F$. enflata: ave $0.96 \pm 0.58$, range $0.46-1.8$ prey per 324 day; Total Chaetognatha: ave $1.36 \pm 1.16$, range $0.64-3.9$ prey per day). The Mediterranean Sea 325 has many ecohydrographic similarities with the Red Sea, e.g. high salinity, low productivity, and 326 zooplankton stock (Gotsis-Skretas et al. 1999). The predation impact of F. enflata varied 
327 between 1.51 and 11.7 (av. $5.8 \pm 4$ ) with an increasing trend towards the north (Supplementary

328 Table 4$)$. The average $( \pm \mathrm{SD})$ predation impact was higher than in the Cretan Passage $(1.3 \pm 0.5)$

329 and Rhodes Sea $(4.8 \pm 1.4)$, but lower than the Ionian Sea $(28.5 \pm 2.8)$ and the Cretan Sea $(21.7 \pm$

330 6) in the Mediterranean. The predation impact of the total Chaetognatha community $(13 \pm 9.8$,

331 range 3.6 - 30.6) showed a similar trend to that of the F. enflata and clearly indicates the

332 significance of this plankton taxon in the trophic energy transfer.

Interestingly, in the upper $100 \mathrm{~m}$, the $\mathrm{C}$ and $\mathrm{N}$ contents of the Chaetognatha community

334 were $26.4 \%$ and $30.7 \%$, of the Copepoda community, which were higher than the estimated

335 predation impact of the total Chaetognatha on the Copepoda (13 \pm 9.8$)$. Compared to the

336 copepods, the relatively larger size of the individuals of Chaetognatha as seen also in the high

337 dry mass per individual (Table 2), might have resulted in asymmetry between the ratio of the

338 elemental composition and the predation pressure of Chaetognatha on the Copepoda.

339 In the subsurface and deeper waters, the Chaetognatha populations of the three mid-depth

340 zones between $100-500$ m were closely ordinated in the NMDS plot (Fig. 7), most likely

341 attributable to the hypoxic conditions at the mid-depths strata. Similar to the observation in the

342 Arabian Sea, the hypoxic waters exerted a profound impact on the vertical distribution of the

343 Chaetognatha community of the Red Sea, but species like Sagitta bipunctata and Serratosagitta

344 pacifica which were found to be mostly restricted to upper waters in the northern Arabian Sea

345 (Kusum et al. 2011), were present in most of the depth zones of the Red Sea. Unlike the northern

346 Arabian Sea, the absence of the acute oxygen depleted waters (DO $<9 \mu \mathrm{mol} \mathrm{kg}{ }^{-1}$ ) in the mid-

347 depth zones of the study region might have permitted these species to inhabit these waters.

348 The intrusion of GAW plays a role in the spatial variability of the Chaetognatha community in the

349 Red Sea, similar to other plankton taxa, e.g. Foraminifera (Siccha et al. 2009). The upper $150 \mathrm{~m}$ 
350 of the southernmost two stations were characterized by relatively low saline, warm, and 351 oxygenated waters which indicated the inflow of GAW into the Red Sea. The importance of the 352 inflow of GAW for the spatial distribution in the Red Sea was also reflected in the high IMD at 353 the two stations in the south with the other sampling locations (Supplementary Table 3). The 354 intragroup $\beta$-dissimilarity was also higher in these southernmost stations. The presence of both 355 low saline waters from the Gulf of Aden in the surface and conversely high saline Red Sea Deep 356 Water at depths may contribute to intra-station community dissimilarity at these two stations 357 compared to other locations where salinity was higher (>40). Earlier Casanova (1985) reported 358 Zonosagitta bedoti as an indicator of the surface inflow of GAW. The limitation of this species' 359 presence to the southern stations up to $18^{\circ} \mathrm{N}$ supports this view. In contrast to previous 360 observations which documented the presence of Pterosagitta draco mostly in the southern part of 361 the Red Sea (Casanova 1986), P. draco was found also in the northern part of the Red Sea in the 362 present study. This implies that the northward advection of GAW influences the distribution of 363 this species farther than expected. This observation also refutes the view of Halim (1969), who 364 noted that the seasonal and geographic distribution of Chaetognatha affords no evidence of 365 dependence on the southern inflow.

366 In the Red Sea, the gradual increase in salinity from south to north is known to set ecophysiological 367 boundaries for faunal assemblage along the basin's axis, e.g. Foraminifera (Fenton et al. 2000; 368 Siccha et al. 2009). Additionally, the wind jet near the Tokar Gap at $19^{\circ} \mathrm{N}$ also plays a role in the 369 ecohydrographic division in the Red Sea as it influences the regional circulation (Stubbings 1939; 370 Zhai and Bower 2013; Abdullah et al. 2018). Although, these factors contributed to the $\beta$ 371 dissimilarity between the locations of the north and south, the majority of species were observed 
372 at most of the sampling locations in varying abundances. These Indo-Pacific species, due to their 373 euryhaline nature, might have survived in this ocean basin.

Another interesting feature that modulated the vertical distribution of the Chaetognatha

375 community was the convective mixing in the northern Red Sea. The downward inclination of the 376 isolines of salinity, temperature and DO at the northernmost station Duba (Fig. 2) corroborates

377 this notion. Association of Chaetognatha with upwelled or downwelled water has been

378 documented before ascertaining their role as indicators of physical processes (Thiriot 1978;

379 Kusum et al. 2014; Nair et al. 2015; Al-Aidaroos et al. 2016). Here, the sinking of water masses

380 associated with the deep water formation in the northern Red Sea is a plausible explanation for

381 higher epipelagic Chaetognatha abundances in deeper layers (Supplementary Table 2).

A total of 17 Chaetognatha species were observed during the present study in the Red

383 Sea. The observed species are all common in the northern Indian Ocean and many of them have

384 Indo-Pacific affinity and are absent from the Atlantic Ocean (Table 1). The importance of

385 Flaccisagitta enflata and Decipisagitta decipens, the dominant species of the upper $300 \mathrm{~m}$ and

$386300-500 \mathrm{~m}$ strata, respectively, concurs with the observation in the northern Indian Ocean (Nair

387 et al. 2015) and suggests similarity in Chaetognatha community structure between these two

388 tropical ecoregions. But, the mesopelagic Eukrohnia fowleri and Pseudosagitta maxima, which

389 often dominate the Chaetognatha community in the $500-1000 \mathrm{~m}$ depth of the northern Indian

390 Ocean (Kusum et al. 2014), were less numerous. The shallow sill of the Bab-al-Mandab (160 m)

391 connecting the Red Sea and the Arabian Sea is considered to limit the presence of the deeper

392 water species in the Red Sea (Casanova 1986). Nevertheless, the occurrence of mesopelagic

393 species in the upper waters in association with upwelling has been reported before (Kusum et al.

394 2014, Nair et al. 2015). This process offers a plausible explanation for their presence in the Red 
395 Sea. In fact, the bathypelagic Chaetognatha in the Arabian Sea like Eukrohnia hamata, E. minuta

and $E$. bathypelagica were absent in the Red Sea, indicating the restriction imposed by the shallow sill on their distribution. The scenario of the restricted abundance of mesopelagic species and absence of bathypelagic species in the Mediterranean Sea (Casanova 1986), which is also connected through a shallow sill to the Atlantic Ocean supports that such barriers are important to understand the distribution of the Chaetognatha.

The number of species recorded from the $1000 \mathrm{~m}$ of Red Sea was relatively low compared to the northern Indian Ocean or the Pacific Ocean (Nair 1978; Pierrot-Bults and Nair 1991). The less variability in the physical variables in this basin compared to that of Indian Ocean or Pacific Ocean might be the reason for the low diversity in the Chaetognatha community of the Red Sea. Similarly, the lower diversity of Chaetognatha in the Persian Gulf (total 12, Furnestin and Codaccioni 1968; Haghi et al. 2010), another hyperhaline semi-enclosed inlet of the Indian Ocean, further supports the view.

The patterns in vertical abundance and the species diversity distribution seem contradictory as both number of species and the species diversity index reached their maximum not at $0-100 \mathrm{~m}$ depth, but at $200-300 \mathrm{~m}$. The higher abundance in the euphotic zone was mainly attributable to epipelagic species, whereas the abundance at $200-300 \mathrm{~m}$ was the result of mixed populations of both epipelagic and mesopelagic Chaetognatha species (Table 1), leading to a higher species diversity at this depth compared to the surface waters. This subsurface diversity maximum of Chaetognatha was in accordance with the earlier observation in the Indian Ocean (Nair 1978; Kusum et al. 2011), as well as with those of Copepoda in the Pacific Ocean (Saltzman and Wishner 1997). 
The varied physiology and the ecohydrographic interrelations of the different maturity

418 stages of the plankton community can be the discernible factors affecting their vertical

419 distributions in the water column (Capitanio and Esnal 1998). The dominance of the immature

420 population throughout the water column observed in the study was consistent with the earlier

421 observation in the surface water from this basin (Al-Aidaroos et al. 2017). The question if mature

422 stages of Chaetognatha are more sensitive to oxygen deficient waters compared to immature

423 stages was also assessed in the present study. Among the five depth layers, the relatively higher

424 abundances of maturing and matured individuals of epipelagic species in the well-oxygenated

425 upper layer may corroborate the notion that mature organisms, due to their higher oxygen

426 demands for egg and sperm production (Wishner et al. 2000) avoid the hypoxic mesopelagic

427 zones and therefore congregate the upper and deeper waters with higher DO.

428

In brief, the macroecology of the Chaetognatha community of the Red Sea was governed

429 by a multitude of indigenous characteristics of this unique ocean basin. The distinct water mass

430 characteristics of GAW, characterized by low salinity, high CDOM and low DO concentration

431 (Zarokanellos and Jones 2018), exerted an important role in structuring the Chaetognatha

432 community. The presence of Zonosagitta bedoti, for instance, can be viewed as an indicator of

433 the surface inflow of GAW as described by Casanova (1985). The evident high $\beta$-dissimilarity

434 between the Chaetognatha community of the southern regions and other sampling locations

435 corroborate the importance of GAW intrusions. The overturning circulation and the sinking of

436 water mass in the north is another physical characteristic of the Red Sea which influenced the

437 vertical distribution of the Chaetognatha community. In addition to this, hypoxic waters in the

438 mid-depth zones of the Red Sea had an important role in the vertical distribution of

439 Chaetognatha. The results of the predation impact and the elemental analysis of Copepoda and 
440 Chaetognatha confirmed the important trophic link between these two prey-predator taxa. The

441 present study providing detailed information on the ecohydrographic drivers that govern the

442 distribution and community structure of a major plankton component of the Red Sea will be

443 important to unravel the macro ecology of this topographically unique but ecologically

444 significant ocean basin in the world ocean.

445 Acknowledgements and Funding

446 This project was funded by the Deanship of Scientific Research (DSR) at King Abdulaziz

447 University, Jeddah, under grant no. RG-1-150-35. The authors, therefore, acknowledge with

448 thanks DSR technical and financial support. We further extend our gratitude towards the

449 Helmholtz-Center for Ocean Research GEOMAR for the successful collaboration (Jeddah

450 Transect Project) with the King Abdulaziz University. The authors also thank the Master and

451 crew of RV Pelagia (cruise 64PE351) for their help in the field. During the writing phase of this

452 manuscript, BK was supported through baseline funds of BHJ (KAUST).

453 Compliance with ethical standards

454 Conflict of interest The authors declare that they have no conflict of interest.

455 Ethical approval

456 All applicable international, national and/or institutional guidelines for the care and use of

457 animals were followed.

458

459

460

461

462

463 


\section{References}

Abdulla CP, Alsaafani MA, Alraddadi TM. Albarakati AM (2018) Mixed layer depth variability in the Red Sea. Ocean Sci 14:563-573.

Al-Aidaroos AM, Salama AJ, El-Sherbiny MM (2016) New record and redescription of Calanopia thompsoni A. Scott, 1909 (Copepoda, Calanoida, Pontellidae) from the Red Sea, with notes on the taxonomic status of $C$. parathompsoni Gaudy, 1969 and a key to species. ZooKeys 552:17-32. doi:10.3897/zookeys.552.6180.

Al-Aidaroos AM, Karati KK, El-Sherbiny MM, Devassy RP, Kürten B (2017) Latitudinal environmental gradients and diel variability influence abundance and community structure of Chaetognatha in Red Sea coral reefs. Syst Biodivers 15:35-48.

Alvariño A (1964). Bathymetric distribution of chaetognaths. Pac Sci 18:64-82.

Anderson MJ, Crist TO, Chase, JM, Vellend M, Inouye BD, Freestone AL, Sanders NJ, Cornell HV, Comita LS, Davies KF, Harrison SP (2011) Navigating the multiple meanings of $\beta$ diversity: a roadmap for the practicing ecologist. Ecol Lett 14:19-28.

Bohata K, Koppelmann R (2013) Chaetognatha of the Namibian upwelling region: taxonomy, distribution and trophic position. PloS one, 8:e53839.

Buchanan PJ, Beckley LE (2016) Chaetognatha of the Leeuwin Current system: oceanographic conditions drive epi-pelagic zoogeography in the south-east Indian Ocean. Hydrobiologia 763:81-96.

Capitanio FL, Esnal GB (1998) Vertical distribution of maturity stages of Oikopleura dioica (Tunicata, Appendicularia) in the frontal system off Valdés Peninsula, Argentina. B Mar Sci 63:531-539. 
Casanova JP (1985) Les Chaetognathes de la Mer Rouge. Rapp. P.-v. Reun Commn Int Explor Scient Mer Mediterr 29:269274.

Casanova JP (1986) Similarity of plankton distribution patterns in two nearly land-locked seas: the Mediterranean and the Red Sea. In: Pierrot-Bults AC, van der Spoel S, Zahuranec BJ, Johnson RK (Eds.) UNESCO technical paper in Marine Science, 49:42-46.

Clarke KR, Gorley RN (2006) PRIMER v6: User Manual/Tutorial. Plymouth, UK: PRIMER-E Ltd.

Devassy RP, El-Sherbiny MM, Al-Sofyani AM, Al-Aidaroos AM (2017) Spatial variation in the phytoplankton standing stock and diversity in relation to the prevailing environmental conditions along the Saudi Arabian coast of the northern Red Sea. Mar Biodivers 47:9951008.

Ducret F (1973). Contribution à l'étude des chaetognathes de la Mer Rouge. Beaufortia 20: 135153.

Echelman T, Fishelson L (1990) Surface zooplankton dynamics and community structure in the Gulf of Aqaba (Eilat), Red Sea. Mar Biol 107:179-190.

El-Sherbiny MM, Hanafy MH, Aamer MA (2007) Monthly Variations in Abundance and Species Composition of the Epipelagic Zooplankton off Sharm El-Sheikh, Northern Red Sea. Res J Environ Sci 1:200-210.

El-Sherbiny MM, Al-Aidaroos AM (2017) A new species of Calanopia (Copepoda, Calanoida, Pontellidae) from the plankton of the central Red Sea. Mar Biodivers 47:1137-1145.

Fenton M, Geiselhart S, Rohling EJ, Hemleben C (2000) Aplanktonic zones in the Red Sea. Mar Micropaleontol 40:277-294. 
Furnestin ML, Codaccioni JC (1968) Chaetognathes du Nord-Ouest de l'Océan Indien (golfe d'Aden, Mer d'Arabie, golfe d'Oman, golfe Persique). Cah ORSTOM Sér Océanogr $6: 143-171$

Giesecke R, González HE (2004) Feeding of Sagitta enflata and vertical distribution of Chaetognatha in relation to low oxygen concentrations. J Plankton Res 26:475-486.

Giesecke R, González HE (2012) Distribution and feeding of chaetognaths in the epipelagic zone of the Lazarev Sea (Antarctica) during austral summer. Polar Biol 35:689-703.

Gotsis-Skretas O, Pagou K, Moraitou-Apostolopoulou M, Ignatiades L (1999) Seasonal horizontal and vertical variability in primary production and standing stocks of phytoplankton and zooplankton in the Cretan Sea and the Straits of the Cretan Arc (March 1994-January 1995). Prog Oceanogr 44:625-649.

Grasshoff K (1969) Zur Chemie des Roten Meeres und des Inneren Golfs von Aden nach Beobachtungen von FS "Meteor" während der Indischen Ozean Expedition 1964/65 Meteor Forschungsergebnisse, Deutsche Forschungsgemeinschaft, Reihe A Allgemeines, Physik und Chemie des Meeres. Gebrüder Bornträger, Berlin, Stuttgart, pp 1-76.

Haghi M, Savari A, Madiseh SD, Zakeri M (2010) Abundance of pelagic chaetognaths in northwestern Persian Gulf. Plankton Benthos Res 5:44-48.

Halim Y (1984) Plankton of the Red Sea and the Arabian Gulf. Deep Sea Res I 31:969-982.

Harris R, Wiebe P, Lenz J, Skjoldal HR, Huntley ME (eds) 2000. ICES Zooplankton Methodology Manual. Academic Press, London.

Kehayias G (2003) Quantitative aspects of feeding of chaetognaths in the eastern Mediterranean pelagic waters. J Mar Biol Ass UK 83:559-569. 
Kimmerer WJ (1984) Selective predation and its impact on prey of Sagitta enflata (Chaetognatha). Mar Ecol Prog Ser 15:55-62.

Kürten B, Khomayis HS, Devassy R, Audritz S, Sommer U, Struck U, El- Sherbiny MM, AlAidaroos AM (2014) Ecohydrographic constraints on biodiversity and distribution of phytoplankton and zooplankton in coral reefs of the Red Sea, Saudi Arabia. Mar Ecol 36:1195-1214.

Kürten B, Khomayis HS, Devassy R, Audritz S, Sommer U, Struck U, El-Sherbiny MM, AlAidaroos AM (2015) Ecohydrographic constraints on biodiversity and distribution of phytoplankton and zooplankton in coral reefs of the Red Sea, Saudi Arabia. Mar Ecol $36: 1195-1214$.

Kürten B, Al-Aidaroos AM, Kürten S, El-Sherbiny MM, Devassy RP, Struck U, Zarokanellos N, Jones BH, Hansen T, Bruss G, Sommer U (2016) Carbon and nitrogen stable isotope ratios of pelagic zooplankton elucidate ecohydrographic features in the oligotrophic Red Sea. Prog Oceanogr 140:69-90.

Kusum KK, Vineetha G, Raveendran TV, Muraleedharan KR, Nair M, Achuthankutty CT (2011) Impact of oxygen-depleted water on the vertical distribution of Chaetognatha in the northeastern Arabian Sea. Deep Sea Res Part I 58:1163-1174.

Kusum KK, Vineetha G, Raveendran TV, Muraleedharan KR, Biju A, Achuthankutty CT (2014) Influence of upwelling on distribution of Chaetognatha (zooplankton) in the oxygen deficient zone of the eastern Arabian Sea. Cont Shelf Res 78:16-28.

Lima ME (2014) Characterization of zooplankton communities associated with an anticyclonic Eddy in the northeast of the islands of Cabo Verde. Doctoral dissertation, Universidade de Cabo Verde. 
553 Maillard C, Soliman G (1986) Hydrography of the Red-Sea and exchanges with the Indian-

$554 \quad$ Ocean in summer. Oceanol Acta 9:249-269.

555 McLaren IA (1969). Population and production ecology of zooplankton in Ogac Lake, a

556 landlocked fiord on Baffin Island. J Fish Res Board Canada 26:1485-1559.

557 Miller AR (1964) Highest salinity in the world ocean. Nature 203:590-591.

558 Nagai N, Tadokoro K, Kuroda K, Sugimoto T (2006) Occurrence characteristics of

559 Chaetognatha species along the PM transect in the Japan Sea during 1972-2002. J

$560 \quad$ Oceanogr 62:597-606.

561 Nair VR (1978) Bathymetric distribution of Chaetognatha in the Indian Ocean. Indian J Mar Sci

$562 \quad 7: 276-82$.

563 Nair VR (2003) Digitized inventory of marine bioresources. Chaetognatha. National Institute of

564 Oceanography. www.nio.org/index/option/comnomenu/task/show/tid/2/sid/18/id/6

565 Nair VR, Kusum KK, Gireesh R, Nair M (2015) The distribution of the Chaetognatha population

566 and its interaction with environmental characteristics in the Bay of Bengal and the

567 Arabian Sea. Mar Biol Res 11:269-282.

568 Øresland V (2000) Diel feeding of the chaetognath Sagitta enflata in the Zanzibar Channel,

569 western Indian Ocean. Mar Ecol Prog Ser 193:117-123.

570 Pierrot-Bults AC, Nair VR (1991) Distribution patterns in Chaetognatha. In: Bone Q, Kapp H,

571 Pierrot-Bults AC (Eds.) The Biology of Chaetognatha. Oxford University, pp 86-116.

572 Reeve MR (1980) Comparative experimental studies on the feeding of chaetognaths and

$573 \quad$ ctenophores. J Plank Res 2:381-393.

574 Saltzman J, Wishner KF (1997) Zooplankton ecology in the eastern tropical Pacific oxygen

575 minimum zone above a sea- mount: 1. General trends. Deep-Sea Res I 44:907-930. 
576 Siccha M, Trommer G, Schulz H, Christoph H, Kucera M (2009) Factors controlling the

577

578

579

580

581

582

583

584

585

586

587

588

589

590

591

592

593

594

595

596

597

598 distribution of planktonic foraminifera in the Red Sea and implications for the development of transfer functions. Mar Micropaleontol 72:146-156.

Sofianos SS, Johns WE (2002) An oceanic general circulation model (OGCM) investigation of the Red Sea circulation, 1. Exchange between the Red Sea and the Indian Ocean. J Geophys Res: Oceans, 107(C11).

Sofianos SS, Johns WE (2003) An oceanic general circulation model (OGCM) investigation of the Red Sea circulation: 2. Three- dimensional circulation in the Red Sea. J Geophys Res: Oceans, 108(C3).

Sofianos SS, Johns WE (2007), Observations of the summer Red Sea circulation, J Geophys Res 112(C6), C06025, doi:10.1029/2006jc003886.

Stubbings HG (1939) The marine deposits of the Arabian Sea: an investigation into their distribution and biology. Trustees of the British Museum, London.

Terazaki M (2013) Feeding of Carnivorous Zooplankton, Chaetognatha. Dynamics and Characterization of Marine Organic Matter, 2, p.257.

Thiriot A (1978) Zooplankton communities in the west African upwelling area. In: Boje R, Tomczak M (Eds.) Upwelling ecosystems. Springer-Verlag, Berlin, p32-61.

Vanden Wollenberg AL. (1977). Redundancy analysis. An alternative for canonical correlation analysis. Psychometrika 42:207-219.

Warwick RM, Clarke KR (1993) Taxonomic distinctness and environmental assessment. J Appl Ecol 35, 532e543.

Wiebe PH, Allison D, Kennedy M, Moncoiffé G (2014) A vocabulary for the configuration of net tows for collecting plankton and micronekton. J Plank Res 37: 21-27 
599 Wishner KF, Ashjian CJ, Gelfman C, Gowing MM, Kann L, Levin LA, Mullineaux LS,

600 Saltzman J (1995) Pelagic and benthic ecology of the Eastern Tropical Pacific oxygen

601 minimum zone. Deep-Sea Res I 42:93-115.

602 Wishner KF, Gowing MM, Gelfman C (2000) Living in suboxia: ecology of an Arabian Sea

603 oxygen minimum zone copepod. Limnol Oceanogr 45:1576-1593.

604 Yoon H, Ko AR, Kang JH, Choi JK, Ju SJ (2016) Diet of Chaetognatha Sagitta crassa and S.

605 nagae in the Yellow Sea Inferred from Gut Content and Fatty Acid Analyses. Ocean

606 Polar Res 38:5-46.

607 Zarokanellos ND, Jones BH (2018) Winter mixing, mesoscale eddies and eastern boundary

608 current: Engines for biogeochemical variability of the central Red Sea during winter/early

609 spring period. Biogeosciences Discuss 2018: 1-44 doi 10.5194/bg-2017-544.

610

Zhai P, Bower A (2013) The response of the Red Sea to a strong wind jet near the Tokar Gap in

612 summer. J Geophys Res Oceans 118:422-434.

612

Zo Z (1973). Breeding and growth of the Chaetognatha Sagitta elegans in Bedford basin. Limnol

613 Oceanogr 18:750-756.

614

615

616

617

618

619

620

621 


\section{$622 \quad$ Figures}

623 Figure 1: Sampling locations in the Red Sea. At the Nereus deep, only physical and chemical 624 variables were measured.

625

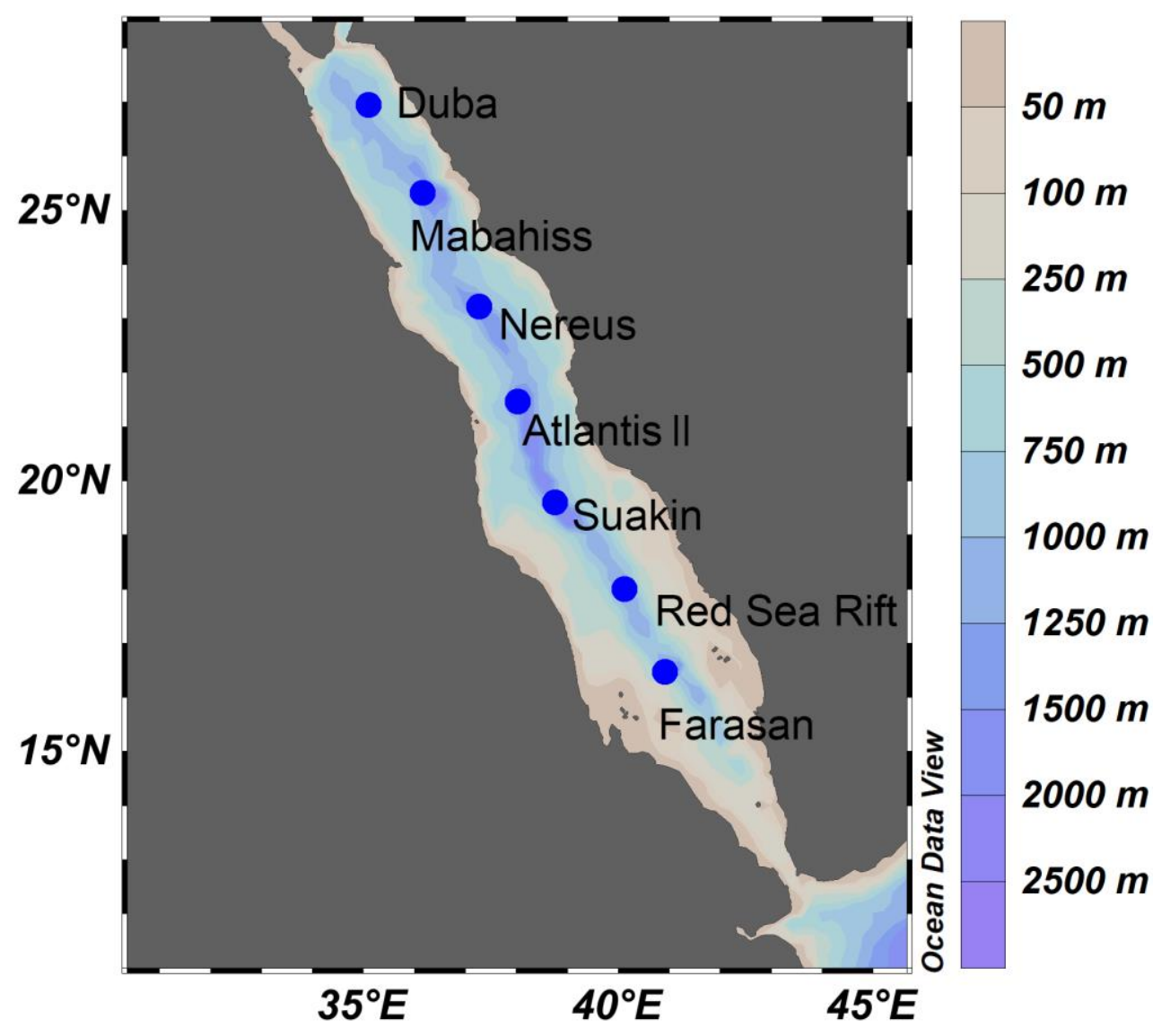


634 Figure 2: Distribution of (a) temperature $\left({ }^{\circ} \mathrm{C}\right),(\mathrm{b})$ salinity, and (c) dissolved oxygen $\left(\mu \mathrm{mol} \mathrm{kg}{ }^{-1}\right)$, 635 in the upper $1000 \mathrm{~m}$ of the Red Sea in April 2012.
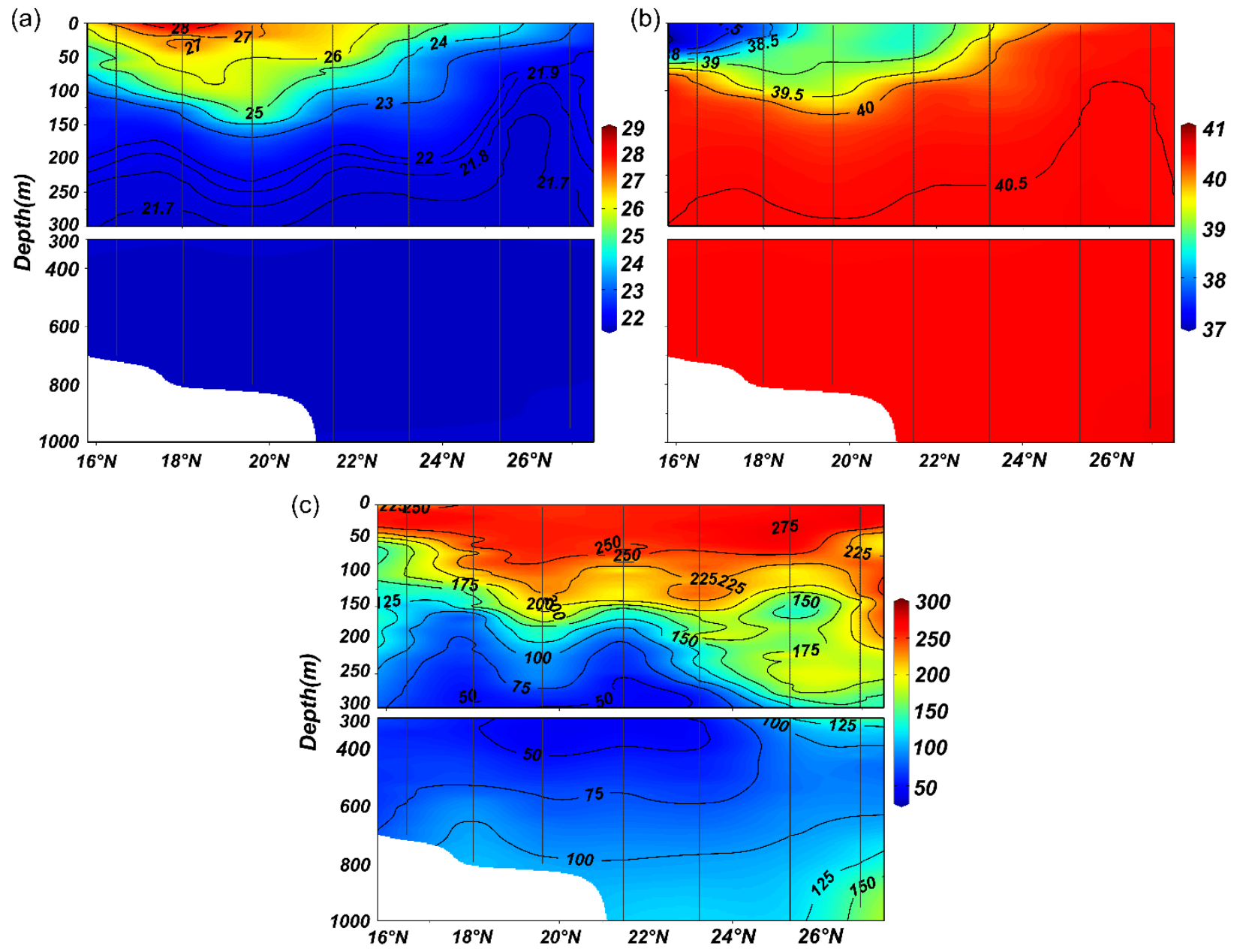
644 Figure 3: Percentage contribution of each Chaetognatha species to total Chaetognatha abundance 645 in each depth layer.

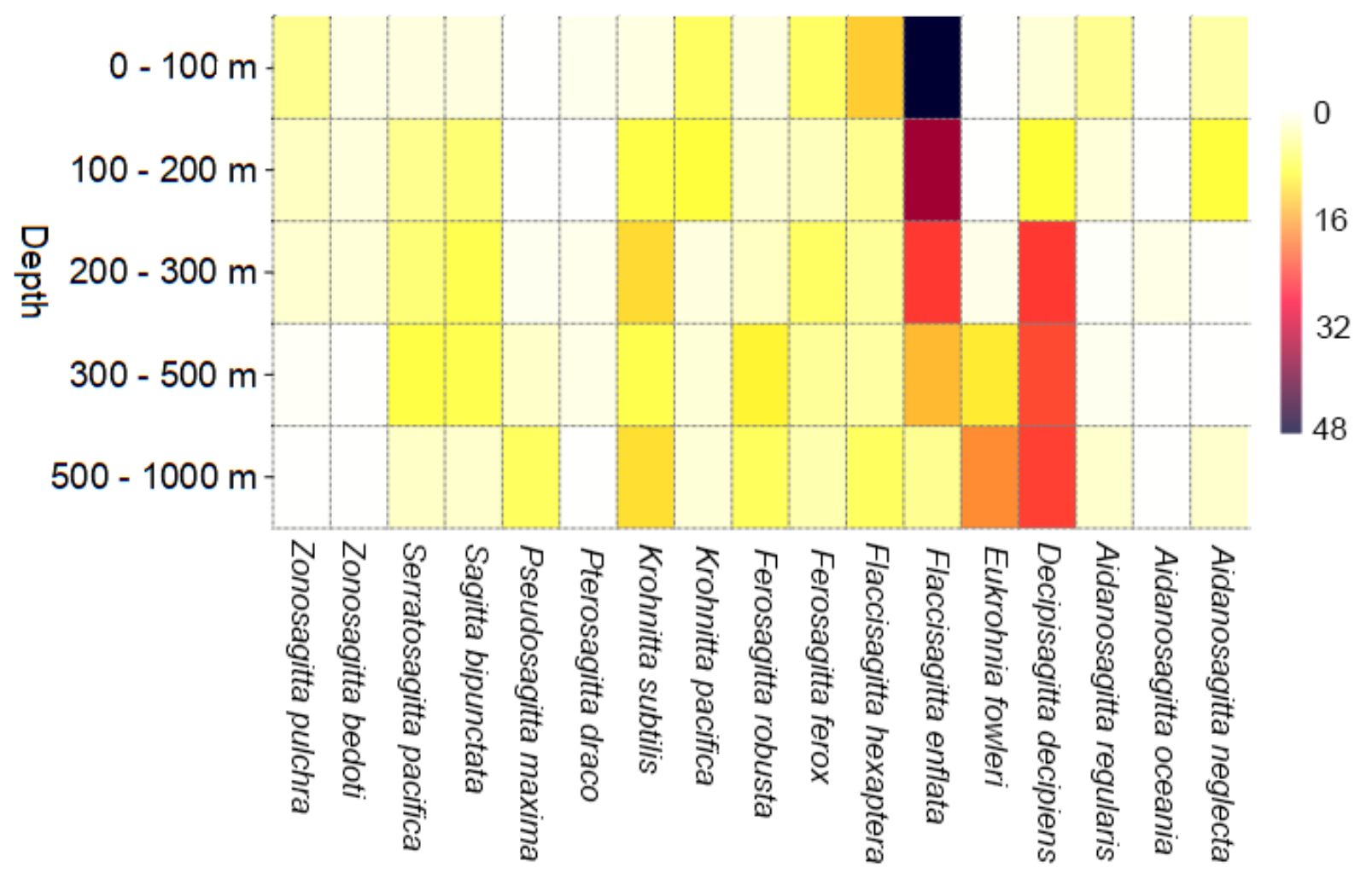

647

648

649

650

651

652

653

654

655

656

657

658 
659 Figure 4: The weighted mean depths $\left(Z_{m}\right)$ of the species of Chaetognatha. (Error bar $\left.= \pm 1 \mathrm{SD}\right)$.

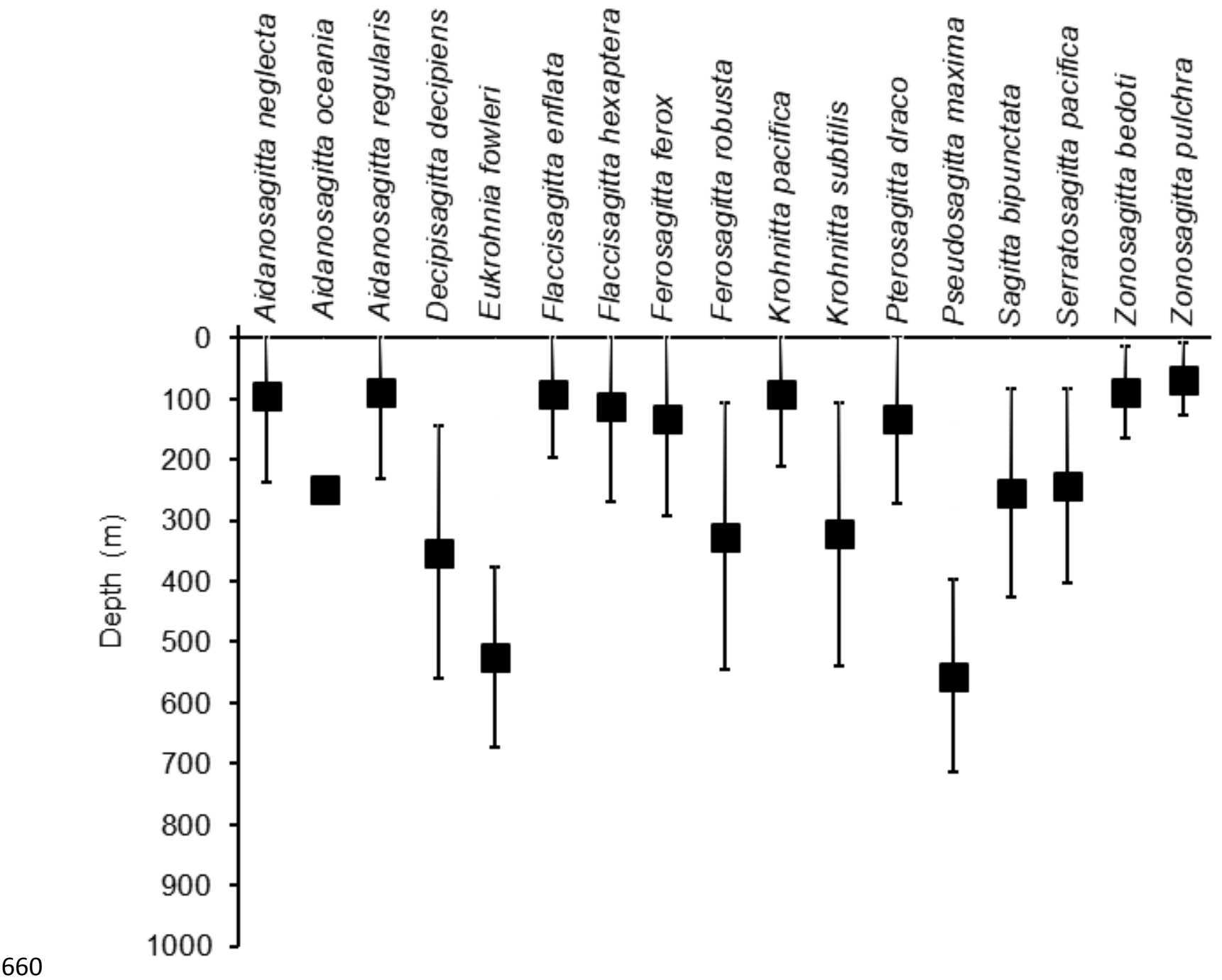

661

662

663

664

665

666

667 
Figure 5: Maturity stage-wise percentage (\%) composition of the species of Chaetognatha at (a) $669100 \mathrm{~m}$, (b) $100-200 \mathrm{~m}$, (c) $200-300 \mathrm{~m}$, (d) $300-500 \mathrm{~m}$, and (e) $500-1000 \mathrm{~m}$.
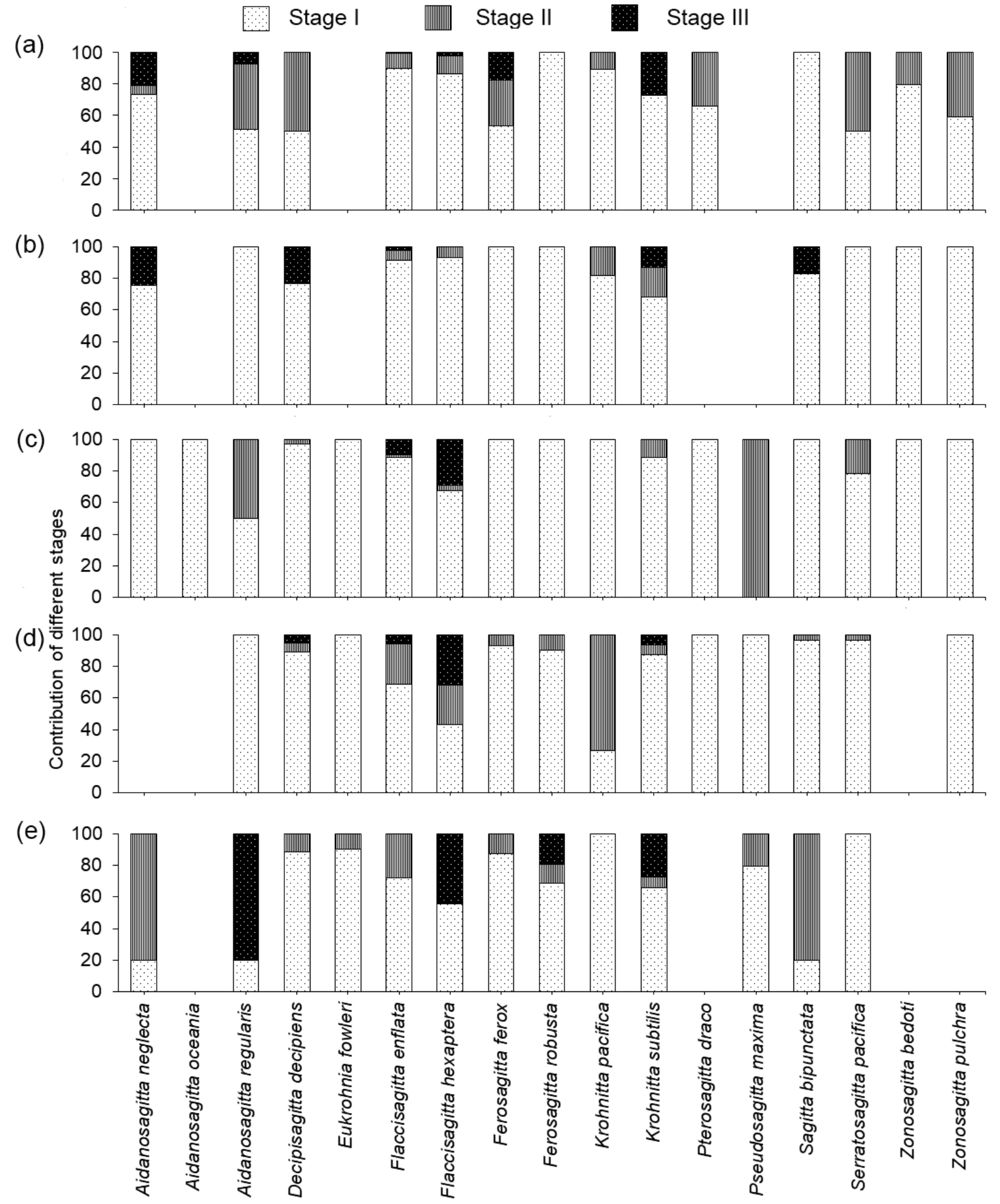
671 Figure 6: The ratio of the abundance of the Copepoda and Chaetognatha along the depth layers.

672 (The lower and upper whiskers display the minimum and maximum values, and the center line in 673 the box indicates the median).

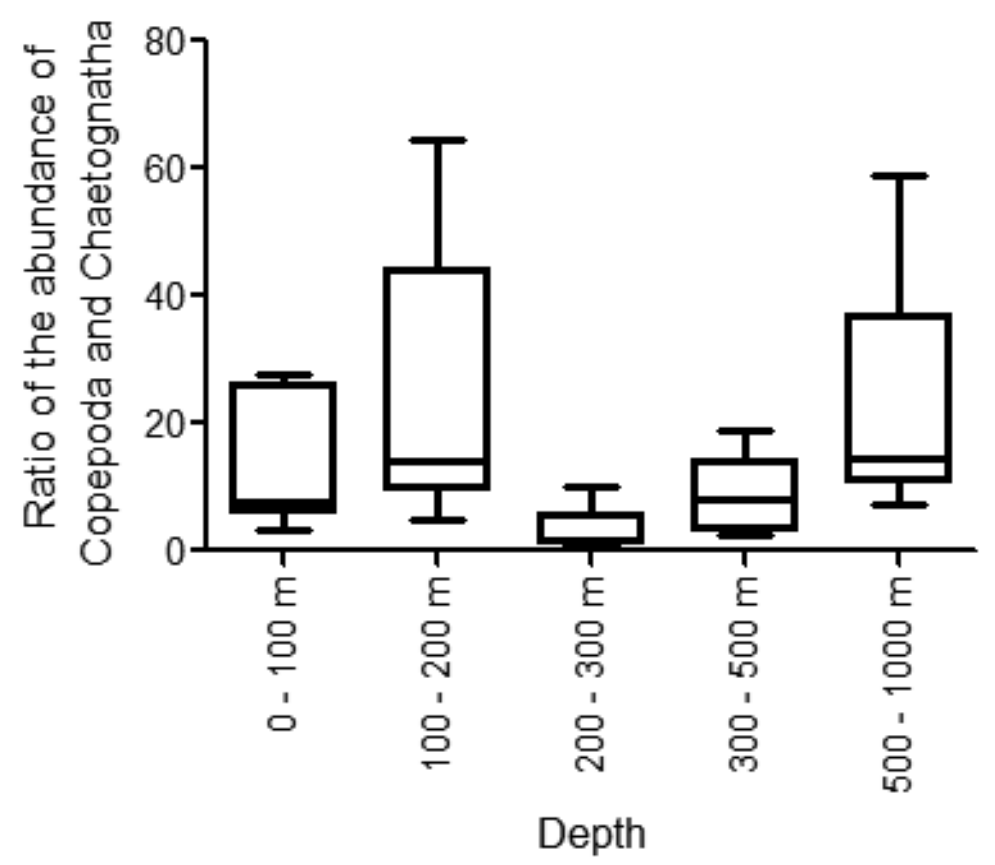

674

675

676

677

678

679

680

681

682

683

684

685 
686 Figure 7: The NMDS plot exhibiting similarity (a) among the depth layers based on the

687 abundance of Chaetognatha species, and (b) among the Chaetognatha species based on their

688 abundance along the depth layers in the station locations. The acronyms of the Chaetognatha

689 species are shown in Table 1.

(a)

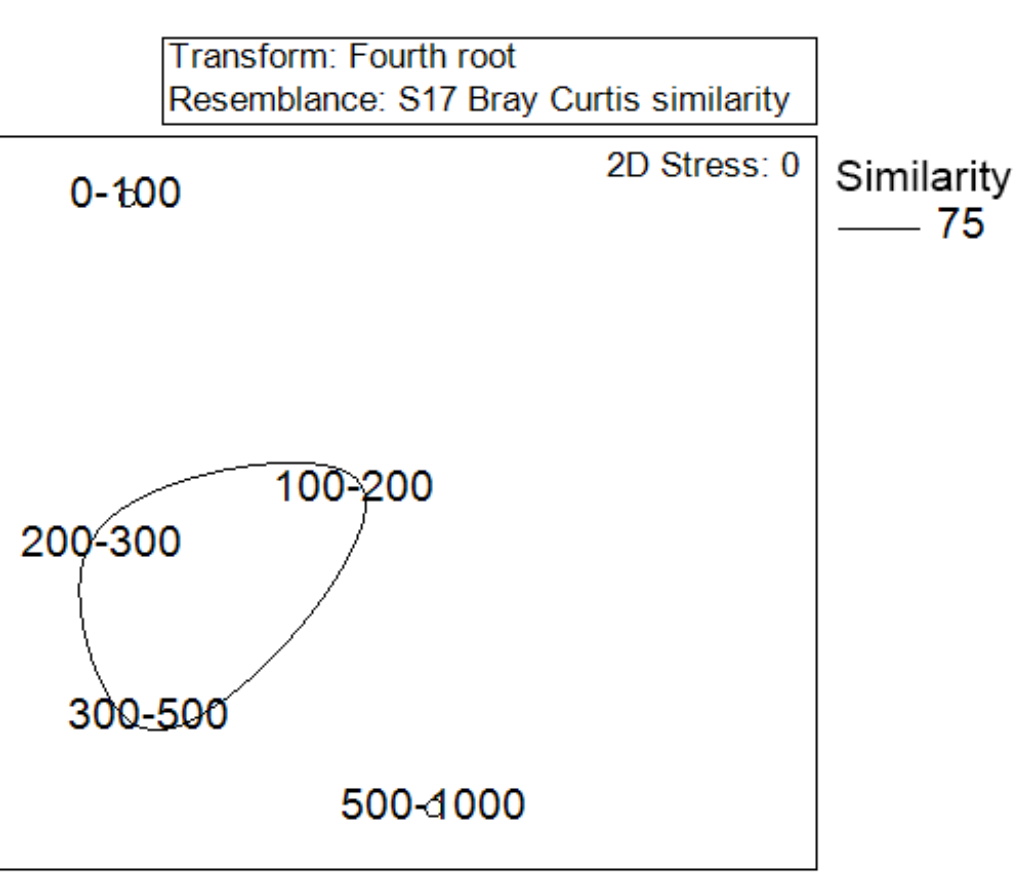

(b)

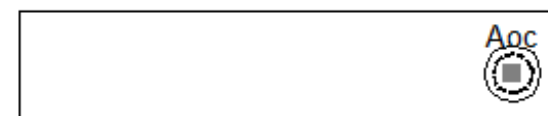

2D Stress: 0.09

Zbe
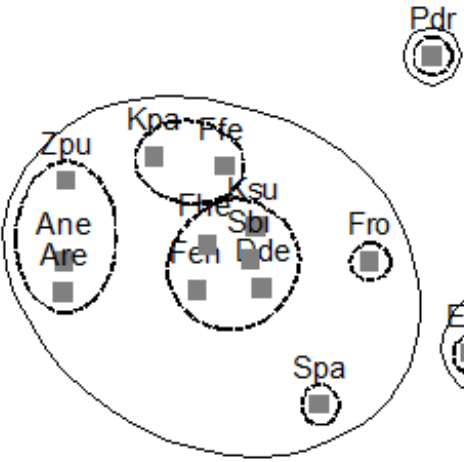

Similarity

$-40$ 
691 Figure 8: The RDA triplot of interrelationships of individual Chaetognatha species with abiotic

692 variables, and Copepoda in the (a) upper $200 \mathrm{~m}$, and (b) $200-1000 \mathrm{~m}$. The acronyms of the

693 Chaetognatha species are displayed in Table 1.

(a)

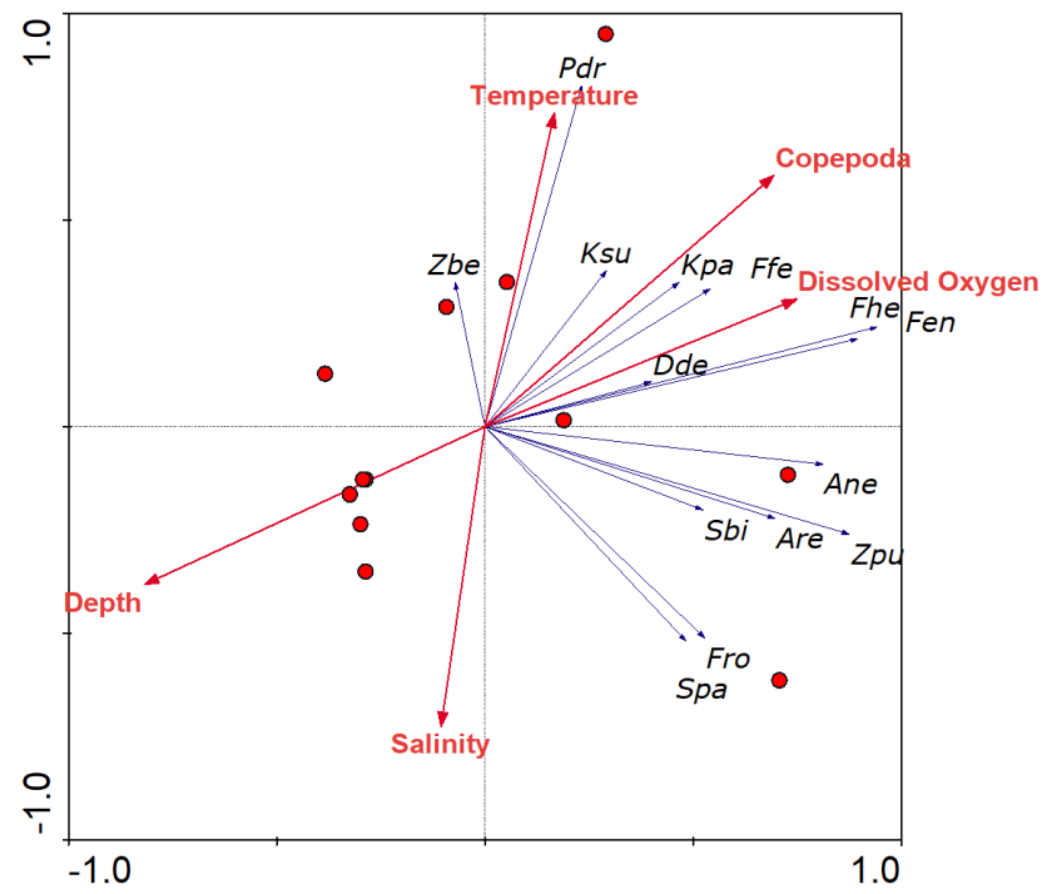

(b)

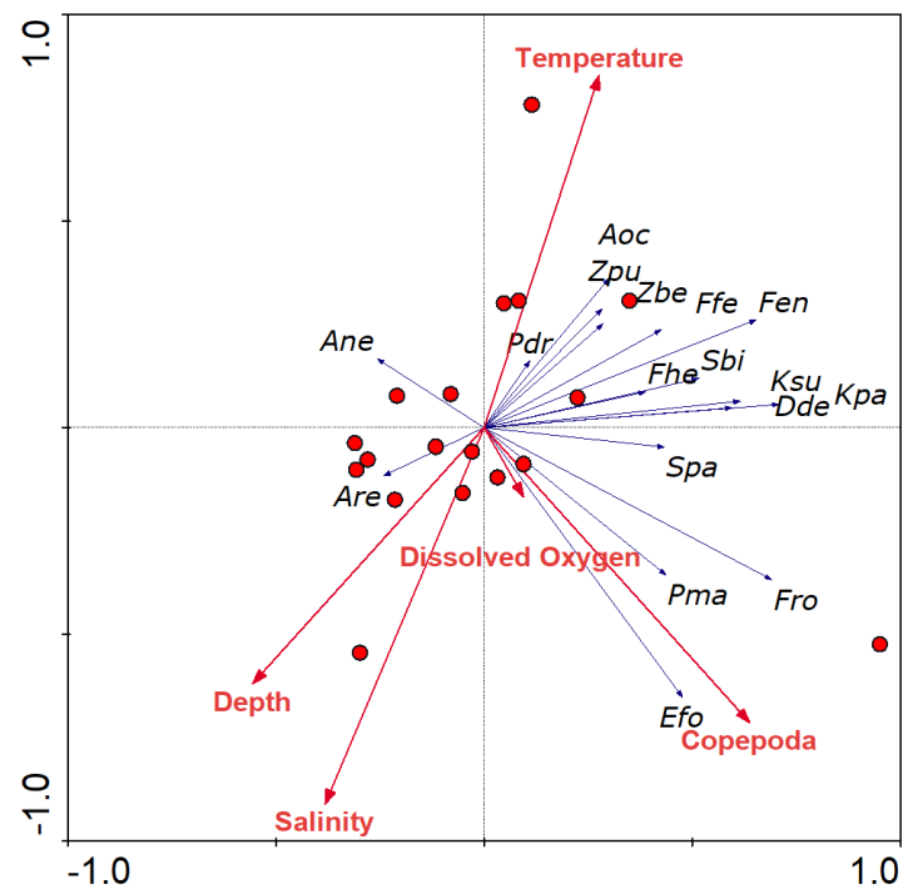


695 Table 1: Abundance of the Chaetognatha (ind $\mathrm{m}^{-3}$ ) in five depth strata in the Red Sea. Along with

696 this ocean basin, their presence and nature of habitat in the tropical region of the three major

697 ocean, and in the Persian Gulf are displayed (AC - Acronyms, RS - Red Sea, PO - Pacific

698 Ocean, IO - Indian Ocean, AO - Atlantic Ocean, PG - Persian Gulf; E - epipelagic, M -

699 Mesopelagic). Excluding the present study, the information on the global distribution of

700 Chaetognatha are based on Alvarino 1964, Nair 1978, Pierrot-Bults \& Nair 1991, Nair et al.

7012015 and other published literatures.

\begin{tabular}{lrrrrrrrrrr}
\hline Species & AC & $0-100 \mathrm{~m}$ & $100-200 \mathrm{~m}$ & $200-300 \mathrm{~m}$ & $300-500 \mathrm{~m}$ & $500-1000 \mathrm{~m}$ & PO & IO & AO & PG \\
\hline Aidanosagitta neglecta & Ane & $0.263 \pm 0.22$ & $0.043 \pm 0.06$ & $0.001 \pm 0.004$ & 0 & $0.004 \pm 0.008$ & $\mathrm{E}$ & $\mathrm{E}$ & - & $\mathrm{E}$ \\
Aidanosagitta oceania & $\mathrm{Aoc}$ & 0 & 0 & $0.01 \pm 0.02$ & 0 & 0 & $\mathrm{E}$ & $\mathrm{E}$ & - & - \\
Aidanosagitta regularis & $\mathrm{Are}$ & $0.331 \pm 0.52$ & $0.008 \pm 0.015$ & $0.002 \pm 0.005$ & $0.005 \pm 0.008$ & $0.004 \pm 0.008$ & $\mathrm{E}$ & $\mathrm{E}$ & - & - \\
Decipisagitta decipiens & $\mathrm{Dde}$ & $0.12 \pm 0.11$ & $0.044 \pm 0.076$ & $0.230 \pm 0.267$ & $0.148 \pm 0.13$ & $0.05 \pm 0.04$ & $\mathrm{M}$ & $\mathrm{M}$ & $\mathrm{M}$ & $\mathrm{M}$ \\
Eukrohnia fowleri & $\mathrm{Efo}$ & 0 & 0 & $0.009 \pm 0.016$ & $0.07 \pm 0.08$ & $0.04 \pm 0.05$ & $\mathrm{M}$ & $\mathrm{M}$ & $\mathrm{M}$ & - \\
Flaccisagitta enflata & $\mathrm{Fen}$ & $3.086 \pm 2.04$ & $0.169 \pm 0.16$ & $0.23 \pm 0.19$ & $0.094 \pm 0.12$ & $0.01 \pm 0.009$ & $\mathrm{E}$ & $\mathrm{E}$ & $\mathrm{E}$ & $\mathrm{E}$ \\
Flaccisagitta hexaptera & $\mathrm{Fhe}$ & $0.865 \pm 0.6$ & $0.024 \pm 0.03$ & $0.045 \pm 0.05$ & $0.027 \pm 0.018$ & $0.014 \pm 0.02$ & $\mathrm{E}$ & $\mathrm{E}$ & $\mathrm{E}$ & $\mathrm{E}$ \\
Ferosagitta ferox & $\mathrm{Ffe}$ & $0.469 \pm 0.71$ & $0.015 \pm 0.02$ & $0.068 \pm 0.117$ & $0.03 \pm 0.034$ & $0.007 \pm 0.01$ & $\mathrm{E}$ & $\mathrm{E}$ & - & $\mathrm{E}$ \\
Ferosagitta robusta & $\mathrm{Fro}$ & $0.091 \pm 0.22$ & $0.010 \pm 0.025$ & $0.026 \pm 0.04$ & $0.066 \pm 0.09$ & $0.014 \pm 0.02$ & $\mathrm{E}$ & $\mathrm{E}$ & - & $\mathrm{E}$ \\
Krohnitta pacifica & $\mathrm{Kpa}$ & $0.472 \pm 0.35$ & $0.043 \pm 0.056$ & $0.014 \pm 0.021$ & $0.012 \pm 0.02$ & $0.003 \pm 0.008$ & $\mathrm{E}$ & $\mathrm{E}$ & $\mathrm{E}$ & $\mathrm{E}$ \\
Krohnitta subtilis & $\mathrm{Ksu}$ & $0.089 \pm 0.079$ & $0.040 \pm 0.06$ & $0.116 \pm 0.15$ & $0.053 \pm 0.08$ & $0.023 \pm 0.03$ & $\mathrm{E}$ & $\mathrm{E}$ & $\mathrm{E}$ & - \\
Pterosagitta draco & $\mathrm{Pdr}$ & $0.053 \pm 0.089$ & 0 & $0.008 \pm 0.016$ & $0.007 \pm 0.01$ & 0 & $\mathrm{E}$ & $\mathrm{E}$ & $\mathrm{E}$ & $\mathrm{E}$ \\
Pseudosagitta maxima & $\mathrm{Pma}$ & 0 & 0 & $0.007 \pm 0.016$ & $0.016 \pm 0.02$ & $0.014 \pm 0.02$ & $\mathrm{M}$ & $\mathrm{M}$ & $\mathrm{M}$ & - \\
Sagitta bipunctata & $\mathrm{Sbi}$ & $0.09 \pm 0.11$ & $0.031 \pm 0.029$ & $0.076 \pm 0.09$ & $0.052 \pm 0.05$ & $0.004 \pm 0.008$ & $\mathrm{E}$ & $\mathrm{E}$ & $\mathrm{E}$ & - \\
Serratosagitta pacifica & $\mathrm{Spa}$ & $0.091 \pm 0.22$ & $0.024 \pm 0.04$ & $0.059 \pm 0.12$ & $0.055 \pm 0.06$ & $0.005 \pm 0.008$ & $\mathrm{E}$ & $\mathrm{E}$ & - & - \\
Zonosagitta bedoti & $\mathrm{Zbe}$ & $0.082 \pm 0.13$ & $0.008 \pm 0.019$ & $0.017 \pm 0.04$ & 0 & 0 & $\mathrm{E}$ & $\mathrm{E}$ & - & $\mathrm{E}$ \\
Zonosagitta pulchra & $\mathrm{Zpu}$ & $0.334 \pm 0.27$ & $0.013 \pm 0.017$ & $0.02 \pm 0.04$ & $0.002 \pm 0.005$ & 0 & $\mathrm{E}$ & $\mathrm{E}$ & - & - \\
\hline
\end{tabular}

702

703

704

705

706

707 
708 Table 2: Average dry weight ( $\mathrm{mg} \mathrm{ind}^{-1}$ ) of the individuals and the elemental composition 709 (percentage of $\mathrm{C}$ and $\mathrm{N}$ ) of Chaetognatha and different genus of Copepoda

\begin{tabular}{lrrr}
\hline & $\mathrm{mg} \mathrm{ind}^{-1}$ & $\mathrm{C} \%$ & $\mathrm{~N} \%$ \\
\hline Chaetognatha & 0.334522 & 34.12 & 9.09 \\
Candacia & 0.077998 & 40.57 & 10.53 \\
Corycaeus & 0.004868 & 38.08 & 7.44 \\
Eucalanus & 0.091634 & 41.71 & 12.58 \\
Euchaeta & 0.115148 & 42.17 & 10.33 \\
Nannocalanus & 0.043338 & 40.98 & 9.57 \\
Pleuromamma & 0.065446 & 44.66 & 11.8 \\
Pontellina & 0.078694 & 37.83 & 7.96 \\
Macandrewella & 0.247665 & 42.48 & 11.33 \\
Macrosetella & 0.004401 & 50.75 & 7.09 \\
Rhincalanus & 0.158483 & 51.65 & 7.36 \\
Copilia & 0.034461 & 23.38 & 5.36 \\
Oncaeidae & 0.00684 & 42.02 & 8.96 \\
Oithona & 0.003708 & 18.07 & 4.23 \\
Sapphirina & 0.023054 & 41.99 & 11.11 \\
Undinula & 0.149606 & 42.9 & 11.3 \\
\hline
\end{tabular}


Click here to access/download

Electronic Supplementary Material (Tables, Figures, Video, Movie, Audio, etc.) Supplementary file.pdf 